\title{
MEMBUMIKAN KONSTITUSI INDONESIA SEBAGAI UPAYA MENJAGA HAK KEBHINEKAAN
}

\author{
Abdul Wahid, Sunardi, Dwi Ari Kurniawati
}

Universitas Islam Malang

Jalan MT Haryono 193, Kelurahan Dinoyo, Kota Malang, 65144

Email: visibos@gmail.com; dr.sunardis@yahoo.com; dwiarik@gmail.com

\begin{abstract}
Indonesian constitution is the foundation of law which regulates the society, nation, and state of people in this country. One thing to highlight in the constitution is in relation with the life concession towards diversity (kebhinekaan) and non-diversity. Every citizen has the right to diversity so that this right demands everyone and anyone for respect. However, there are still several people who do not respect this right to diversity in the society. It could be proven by many people imposing their opinion, attitude, and behavior to others even though it is evident that this shows the practice of unconstitutionality. Based on these problems, it is necessary to have a discussion regarding how to ground the Indonesian constitution as an effort to safeguard the right to diversity. Constitutionality means that there is recognition, that every Indonesian citizen has the right to diversity, so that this right requires every person or party to respect him, and not harass or play with him.
\end{abstract}

Key words: Diversity, Rights, Constitution, Citizen

\begin{abstract}
ABSTRAK
Konsitusi Indonesia merupakan hukum dasar yang mengatur kehidupan bermsyarakat, berbangsa, dan bernegara bagi rakyat di negara ini. Salah satu yang digariskan dalam konstitusi adalah mengenai pengakuan hidup atas keragaman (kebhinekaan), dan bukan keragaman. Setiap warga negara mempunyai hak kebhinekaan, sehingga hak ini menuntut setiap siapapun atau pihak manapun untuk menghormatinya. Sayangnya, di tengah masyarakat, masih banyak pihak yang tidak menghormati hak kebhinekaan ini. Terbukti tidak sedikit pihak yang memaksakan pendapat, sikap, dan perilakunya pada orang lain untuk mengikutinya, meskipun jelas-jelas ini merupakan wujud praktik inkonstitusionalitas. Berdasarkan permasalahan tersebut maka perlu adanya pembahasan terkait bagaimana cara untuk membumikan konstitusi indonesia sebagai upaya menjaga hak kebhinekaan. Secara konstitusionalitas berarti ada pengakuan, bahwa setiap warga negara Indonesia mempunyai hak kebhinekaan, sehingga hak ini menuntut setiap siapapun atau pihak manapun untuk menghormatinya, dan bukan melecehkan atau mempermainkannya.
\end{abstract}

Kata kunci: Kebhinekaan, Hak, Konstitusi, Warga Negara

\section{PENDAHULUAN}

Pola sikap dan perilaku yang bercorak merekahkan konstruksi kesatuan dan kedamaian bangsa masih sering mencuat akibat adanya sekelompok orang atau organisasi yang menghadirkan gaya monologis dan eksklusif yang menempatkan dirinyalah yang paling benar, paling nasionalistik, dan wajib diikuti atau dijadikan sumber klaim kebenaran, sementara seseorang atau 
kelompok lainnya sebagai yang bersalah dan tersesat jalan.

Fenomena seperti itulah yang terbaca sebagai model seseorang dan sekelompok orang yang sejatinya tidak paham kebhinekaan, sehingga pemikiran dan perilakunya harus direkonstruksi secara terus menerus. Mereka wajib diajari, dididik, atau diedukasikan supaya menjadikan Indonesia tetap sebagai "rumah" besar (negara kesatuan) yang memayungi keragaman etnis, golongan, agama, politik, budaya, dan lainnya. Perlu dipahami atau diketahui bahwa Negara Indonesia adalah Negara Kesatuan yang berbentuk Republik ketentuan ini termaktub dalam pasal 1 ayat 1 Undang-Undang Dasar Negara Republik Indonesia Tahun 1945. Indonesia sebagai sebagai negara yang demokratis berkonstitusi, catatan historis timbulnya negara konstitusional merupakan proses sejarah yang panjang dan selalu menarik untuk dikaji. ${ }^{1}$

Indonesia sebagai negara kebangsaan dituntut untuk mengelola dengan baik dan hati-hati agar demokrasi dan integrasi bisa berjalan tanpa saling meniadakan. ${ }^{2}$ Tuntutan pada setiap subyek bangsa ini sangat logis, karena tidak sedikit diantara elemen bangsa ini yang belum benar-benar memahami urgensinya hidup dalam kehidupan berkebangsaan (nasionalisme), atau masih dikuasai oleh semangat dan pembelaan kepentingan individualisme, primordialisme, dan kekuatan tertentu yang menguntungkan kepentingan eksklusifismenya, sehingga dengan kondisi demikian ini, tampaknya harus dilakukan pengedukasian secara etik dan masif.

Pengedukasian terhadap pemahaman negara kesatuan atau paham kebangsaan itu bukan hanya menjadi wujud pengakuan terhadap eksistensi hak keberagaman setiap subyek bangsa ini, tetapi juga sekaligus sebagai bentuk penguatan realitas historis dan sosiologisnya. Langkah ini penting sebagai wujud gerakan riil deradikalisasi dan penyebaran atau pembumian kecerdasan nurani berbasis pemedulian kemanusiaan. Filosof Cicero menyatakan, mea mihi conscientia pluris est quam omnium sermo atau hati nurani saya bernilai lebih banyak daripada semua khotbah. ${ }^{3}$

Pandangan Cicero itu secara tidak langsung mengisyaratkan, bahwa pemosisian model intoleransi dan eksklusifisme sebagai wujud gerakan pembeneran radikalisme berdalih demi agama atu keadilan dan semacamnya oleh seseorang dan segolongan orang harus dijawab dengan memperbanyak pencerdasan rasionalitas, penguatan nurani,

\footnotetext{
${ }^{1}$ Ni'matul Huda, (2008), UUD 1945 dan Gagasan Amandemen Ulang, Jakarta: Raja Grafindo Persada, hlm. 1.

${ }^{2}$ Moh Mahfud MD, (2009), Konstitusi dan Hukum Dalam Kontroversi Isu, Jakarta: Raja Grafindo Persada, hlm. 35 .

${ }^{3}$ Mochtar Hariri, (2015), Menjaga Negara Kebangsaan di Tengah Multikulturalisme, Jakarta: Leterasi-press, hlm. 4.
} 
atau aksi-aksi deradikalisasi dengan mengajarkan atau mengedukasikan pemahaman dan model perilaku demokratisasi, humanisasi, nasionalisasi, dan inklusifitas secara berkelanjutan di tengah multikultualisme ini. Masalahnya siapa yang harus gencar menyuarakan atau melakukan pembumian terhadap hak-hak konstitusionalitas warga, khususnya hak kebhinekaan ini.

\section{PEMBAHASAN}

Pengedukasikan sikap dan perilaku kebhinekaan itu juga dapat dikorelasikan dengan kondisi riil masyarakat multicultural di Indonesia. Artinya realitas keindonesiaan tidaklah bisa dipaksakan harus berada dalam payung hegemoni keseragaman.

Mantan Ketua PBNU A. Hasyim Muzadi pernah menyebut bahwa Indonesia adalah suatu negara yang multikultural terbesar di dunia. Stigma demikian berangkat dari etnografis Indonesia yang begitu beragam dan dari sisi geografisnya yang begitu luas. Misalnya Indonesia mempunyai bentangan wilayah sekitar 13.000 pulau besar dan kecil yamg dihuni oleh penduduk kurang lebih 250 juta jiwa, yang terdiri tidak kurang dari 300 suku, yang menggunakan hampir 200 bahasa daerah yang berbeda, dan menganut agamaagama resmi (Islam, Katholik, Kristen, Hindu, Budha, dan Konghucu), di samping beberapa kepercayaan yang diyakini oleh sebagian penduduk.

Dalam deskripsi lain disebutkan, bahwa bangsa Indonesia adalah bangsa yang kaya akan budaya, suku, ras dan agama. Hal tersebut sangat berkaitan dengan jiwa nasionalisme bangsa Indonesia. Berbagai masalah yang dihadapi oleh bangsa Indonesia mulai dari kemiskinan, pengangguran, terorisme dan lain sebagainya, menimbulkan banyak persoalan. Penyebabnya, di antaranya adalah rendahnya rasa nasionalisme bangsa Indonesia. Hal itu tidak bisa dipungkiri, pasalnya masyarakat lebih memilih untuk kelangsungan hidupnya daripada memikirkan untuk negara. Tinggi atau rendahnya nasionalisme juga dapat dipengaruhi faktor budaya barat yang dengan mudahnya masuk dan memengaruhi pola pikir budaya Indonesia. ${ }^{4}$ Sebagian orang menganggap ini sebagai problem, padahal inilah justru diantaranya yang membuat multikulturalisme sebagai kekayaan tersendiri bangsa Indonesia, yang mengundang (menuntut) semua elemen bangsa untuk menyadari dan mensyukuri realitas karunia besar ini.

Kondisi multikultralisme itu menjadi kekayaan masyarakat Indonesia, adalah sudah diakui oleh masyarakat dunia. Masayarakat internasonal mengajak atau melibatkan Indonesia sebagai mitra secara ekonomi dan politik adalah berkaitan dengan kekayaan

\footnotetext{
${ }^{4}$ Marsudi AR, Merajut Nasionalisme dalam Bingkai Kebhinekaan, http://banjarmasin.tribunnews.com/2017/01/26/merajutnasionalisme-dalam-bingkai-kebhinnekaan, akses 1 April 2019.
} 
yang dimilikinya. Jika kekayaan ini diposisikannya sebagai sumberdaya strategis, maka berbagai langkah pengembangan atau pemajuan HAM tidak sampai mengalami kesulitan, dan bahkan dapat menjadi kekuatan untuk mencegah terjadinya potensi yang mengancam integrasi bangsa seperti radikalisme, terorisme dan ekstrimisme.

Setiap elemen bangsa ini semestinya memahami, bahwa kekayaan berbentuk kebhinekaan di berbagai sisi kehidupan tidak selalu dimiliki oleh setiap bangsa di dunia, meski di setiap bangsa ini, selalu ada kebhinekaan atau keragaman. Bangsa Indonesia memiliki kebhinekaan akibat banyak aspek yang mempengaruhinya. ${ }^{5}$ Kekayaan besar dan istimewa yang dimiliki bangsa Indonesia ini merupakan anugerah Tuhan yang tidak ternilai. Untuk memuliakan anugerah besarNya ini, diserahkanlah pada manusia Indonesia sendiri dalam merawat atau mensyukurinya. Keragaman atau kondisi pluralitas budaya, agama, sosial, etnis, dan lainnya tidak perlu dipertentangkan karena masing-masing mengandung keistimewaan.

Di era milenial ini, setiap subyek hidup bermasyarakat dan berbangsa ini justru harus terus menerus dididik atau dibentuk di ranah apapun, seperti dimulai dari keluarga, sekolah dasar hingga perguruan tinggi supaya mereka bukan hanya menjadi manusia-manusia yang rela menjadi subyek penegak hak kebhinekaan, tetapi juga berupaya membentuk dirinya dimanapun dan saat kapanpun untuk menjadi kekuatan yang militan dalam mewujudkan sakralitas dan fundamentalitas hak keberbhinekaan secara meluas (universalitas).

Militansi dalam berkebhinekaan di era melinial ini harusnya menyala dan memang mengalami progresifitas di dada setiap subyek bangsa, karena di ranah meluasnya keberagaman, setiap subyek dituntut menalar dan mengadaptasikan diri secara cerdas seiring dahsyatnya akselerasi perubahan Iptek dan godaan tantangan yang beragam, sementara realitas kondisi obyektif masyarakat sendiri sudah pluralitik atau multikltural, yang jika kondisi ini tidak disikapi atau dikelola dengan cerdas dan etis, potensial bisa membahayakan keutuhan hidup bermasyarakat dan berbangsa.

Akselerasi tantangan dan eksaminasi itu juga semakin terasa pasca kegiatan seperti pesta demokrasi (Pemilu). Terbukti, tidak sedikit subyek politik yang terseret dalam euforia "memanaskan" stigma kemenangan dan egoisme kelompok atau komunitas politik dan agama tertentu, diantaranya dengan menabur dan menguatkan klaim-klaim yang tidak obyektif atau ujaran-ujaran kebencian, padahal semestinya mereka berkewajiban menjaga harmoni di tengah keragamannya. Idealitasnya, mereka tidak menciptakan

\footnotetext{
${ }^{5}$ Kholilurrahman Saad, (2015), Kewajiban Bela Negara: Menjaga Kebhinekaan Indonesia, Bandung: Kalimas, hlm. 3.
} 
kondisi demikian, jika mereka secara jernih menyadari, bahwa perbedaan mestilah akan terjadi dalam momentum apapun yang dilaksakan di negara ini, apalagi momentum agama dan politik.

Mereka tentu bisa membaca, bahwa khusus agama-agama dan kepercayaan saja tersebar di semua wilayah Indonesia, yang penyebarannya ini menunjukkan adanya realitas kebhinekaan, sehingga tidak berlebihan untuk menyebutnya sebagai kenyataan menusantaranya kebhinekaan di negara ini. Meskipun ada perbedaan (keragaman) dalam jumlah prosentase penganutnya. Secara umum, penganut agama Islam memnag tersebar sekitar $87 \%$, namun ada beberapa propinsi yang didominasi penganut agama lain, seperti propinsi Bali yang penduduknya sekitar $82 \%$ beragama Hindu, Nusa Tenggara Timur (NTT) menganut agama Katholik (sekitar 80\%), dan Irian Jaya yang penduduknya mayoritas $75 \%$ ) menganut agama Kristen Protestan.

Keragaman itulah yang idealitasnya membuat kita, kuhusnya komunitas elitis "pemain" politik dalam penyelenggaraan demokrasi berkewajiban menjalankan dan memprogresifitaskan hak kebhinekaan dalam beragama atau bermasyarakat dengan cerdas dalam bingkai kemanusiaan. Hertz dalam Abu Daud Busro, bahwa democrasi is a form of government in which no one member has political prerogatif over any other government is this the rule of all over. All in the common as appored to the individual or saparate group interest (demokrasi adalah semacam pemerintahan dimana tidak seorang anggota masyarakat yang mempunyai hak prerogatif politik atas orang lain, jadi pemerintahan yang pada umumnya dilakukan oleh semua bentuk. Semua sebagaimana dilawankan terhadap kepentingan perseorangan atau kepentingan kelompok). ${ }^{6}$ Pikiran ini menunjukkan, bahwa dalam konstruksi pemerintahan yang menganut system demokrasi, pengakuan keragaman identik deangan pengakuan terhadap hak yang tumbuh berkembang di semua unsur masyarakat.

Kecerdasan nalar dan etik akan bisa terbaca dalam relasi inklusif dan berkeadaban antar pemeluk agama, produsen budaya, paedagog, pelaku politik, dan lainnya. Perbedaan mesti ditoleransi dan didemokratisasi secara rasional dan lapang dada, serta konstitusionalitas. Artinya perbedaan dalam segala aspek kehidupan mesti disikapi secara rasional, legal, dan konstruktif untuk mewujudkan kesatuan dalam keberagaman dalam negara yang menganut prinsip hukum.

Ada beberapa unsur rule of law menurut A.V. Dicey sebagaimana berikut:

\footnotetext{
${ }^{6}$ Abu Daud Busro dan Abu Bakar Busro, (1983), Asas-asas Hukum Tata Negara, Jakarta: Ghalia Indonesia, hlm. 131.
} 
1. supremasi aturan-aturan hukum (the absolute supremacy or predominance of regular law);

2. kedudukan yang sama dihadapan hukum (equality before the law, or the equal subjection of all classes to the ordinary law of the land administrated by ordinary law courts);

3. adanya jaminan terhadap hak-hak asasi manusia (a formula expressing the fact that with us the law of constitution, the rules which in foreighn countries naturally form parts of a constitutional code, are not the source but the consequence of the rights of individuals as defined and enforced by the countries). ${ }^{7}$

Hak kebhinekaan merupakan hak yang dijamin oleh sejumlah norma di dunia. Di negeri ini, setiap pemeluk agama misalnya dijamin hak beragamanya secara konstitusional, sehingga setiap pemeluk agama berkewajiban menegakkan hak kebhinekaan ketika pemeluk agama lainnya menjalankan aktifitas spiritualitasnya.

Secara konstitusionalitas, Pasal 28E ayat (1) Undang-undang Dasar 1945 menggariskan, setiap orang bebas memeluk agama dan beribadat menurut agamanya. Dalam ayat (2) berbunyi, setiap orang berhak atas kebebasan meyakini kepercayaan, menyatakan pikiran, dan sikap, sesuai dengan hati nuraninya.

Selain itu, kebebasan beragama juga diatur dalam Pasal 29 ayat (2) bahwa, negara menjamin kemerdekaan tiap-tiap penduduk untuk memeluk agamanya masing-masing dan untuk beribadat menurut agamanya dan kepercayaannya itu.

Kalau berpijak pada norma konstitusi itu, maka sudah jelas bahwa dalam sistem ketatanegaraan atau konstruksi kehidupan bernegara, sistem konstitusonlitas Indonesia mengakui kebhinekaan. Sistem kehidupan bernegara kita sejatinya menganut salah satu "habitat" manusia yang mengakui keragaman. Keragaman seharusnya menyadarkan setiap subyek bangsa ini, bahwa Indonesia adalah 'rumah besar" yang harus dijaga atau dilindunginya dari berbagai kemungkinan buruk atau ancaman yang bermaksud atau bermodus menubuhkan atau menghancurkannya.

Dalam soal sistem, Carl J. Friedrich mengungkapkan bahwa sistem merupakan suatu keseluruhan, terdiri dari beberapa bagian yang mempunyai hubungan fungsional baik antara bagian maupun hubungan fungsional terhadap keseluruhan, sehingga hubungan itu menimbulkan ketergantungan antara bagian-bagian yang akibatnya jika salah satu bagian tidak bekerja dengan baik

\footnotetext{
7 A.V. Dicey, (1971), An Introduction to the Study of the law of the Constitution, London: English Language Book Society and Mac Hillan, hlm. 202-203.
} 
akan mempengaruhi keseluruhannnya itu. ${ }^{8}$ Dalam ranah ini, logis jika dalam kontruksi sistem hukum Indonesia, yang menempatkan konstitusi sebagai rujukan utamanya menjadi sangat menentukan peta kehidupan bermasyarakat dan berbangsa, yang dalam tatakelonya mendasarkan pada konstitusi.

Untuk menerjemahkan perintah konstitusi, produk hukum dibawahnya, yang merupakan konsekuensi dari konstruksi sistem hukum di Indonesia juga sudah mengaturnya, misalnya jaminan hak kebebasan berkebhinekaan secara yuridis juga dapat dilihat dalam Undang-Undang Nomor 12 Tahun 2005 tentang Pengesahan International Covenant on Civil and Political Rights (Kovenan Internasional tentang Hak-Hak Sipil dan Politik). Dengan ratifikasi ini, maka Indonesia menjadi Negara Pihak (State Parties) yang terikat dengan isi ICCPR. Kovenan ini menetapkan hak setiap orang mempunyai atas kebebasan berpikir, berkeyakinan dan beragama serta perlindungan atas hak-hak tersebut (Pasal 18).

Ketentuan-ketentuan tersebut sudah jelas menunjukkan, bahwa di negara ini setiap orang berhak bebas menjalankan dan mengembangkan kebhinekaannya, khususnya dalam menjalankan doktrin agamanya, baik yang beragama Islam, Kristen, Budha, Hindu, Konghucu, maupun keyakinan lainnya. Siapapun dan kekuatan apapun dilarang dan dari golongan manapun keras memproduksi pola kebencian dalam beragama, dan sebaliknya harus menunjukkan sikap dan perilaku toleran terhadap pemeluk agama lainnya.

Terorisme merupakan salah satu jenis radikalisme yang terbukti telah menjadi jenis kekerasan memprihatinkan yang membuat terjadinya disharmonisasi sosial dan rentannya hubungan lintas agama yang diwarnai serba praduga bersalah (presumption of guilt). Radikalisme demikian merupakan praktik inkonstitusionalitas, yang tentu saja membahayakan konstruksi kehidupan berbangsa.

Kondisi yang terbaca, bahwa seringkali subyek sosial dan agama melakukan kekerasan atau radikalisme hanya demi menunjukkan kalau diri dan kelompoknya yang paling benar, sementara seseorang atau pihak lainnya sebagai obyek yang bersalah, dan terkesan dituntut menyingkir dari konstruksi kehidupan bermasyarakat dan bernegara. Dalam ranah inilah, akhirnya berbagai bentuk pelanggaran HAM keberagaman seperti peecehan terhadap hak berbeda yang bersifat serius rentan terjadi dan meluas di masyarakat.

Seharusnya seseorang atau sekelompok orang dari pihak atau golongan apapun berusaha terus menerus mengembangkan dirinya sebagai subyek pelindung dan

\footnotetext{
${ }^{8}$ Hestu Cipto Handoyo, (2009), Hukum Tata Negara Indonesia, Yogyakarta: Penerbit Universitas Atma Jaya, hlm. $117-118$.
} 
pengadvokasi hak keberagaman. Progresifitas ini menuntutnya guna menciptakan dan membumikan kultur saling menghormati atau mengapresiasi antar masing-masing orang dalam keragamannya. Diantara mereka yang bertanggungjawab melakukannya adalah segenap pemimpin daerah. Penyelenggaraan pemerintahan di daerah, terutama yang berkaitan dengan kedudukan da peran Kepala Daerah merupakan salah satu tuntutan reformasi yang diinginkan masyarakat di daerah, ${ }^{9}$ dimana dalam perannya ini mengandung kemuliaan jika diperankannya secara konstitusional atau diorientasikan membumikan norma-norma konstitusi.

Setidaknya setiap subyek bangsa, khususnya kalangan penyelenggaranegara dapat menempatkan kehadiran Mahkamah Konstitusi dalam kaitannya dengan urgensinya kehadiran konstitusi. Jimly Asshiddiqie menyebutkan bahwa konstitusi sebagai hukum tertinggi mengatur penyelenggaraan negara berdasarkan prinsip demokrasi dan salah satu fungsi konstitusi adalah melindungi hak asasi manusia yang dijamin dalam konstitusi sehingga menjadi hak konstitusional warga negara. Oleh karena itu, Mahkamah Konstitusi berfungsi sebagai pengawal demokrasi, pelindung hak konstitusional warga negara serta pelindung
HAM. ${ }^{10}$ Peran demikian bukan semata menunjukkan urgensinya kehadiran Mahkamah Konstitusi dalam mengawal konstitusi, tetapi juga untuk membuka ruang intelektualitas dan kesadaran batin setiap subyek bangsa, bahwa konstitusi itu sangat penting dalam kaitannya dengan kepentingan fundamental kehidupan bermasyarakat, berbangsa, dan bernegara.

Kalangan pembelajar bisa membaca, bahwa landasan normatif penyelenggaraan pemerintahan daerah terus berubah dalam beberapa kurun waktu tertentu, yang ikut mengubah arah perubahan politik pemerintahan. Kondisi ini telah memberi warna tersendiri dalam pola kegiatan, pola kekuasaan dan pola perilaku kepemimpinan Kepala Daerah, ${ }^{11}$ yang tentu saja seharusnya ikut mewarnai dalam pembumian atau progresifitas konstitusi di daerah, khususnya yang berkaitan dengan upaya menegakkan hak kebhinekaan, karena tidak jarnag ditemukan sejumlah konflik di daerah yang berkaitan dengan kultus etnis dan budaya, yang mengakibatkan terjadinya pertumpahan darah

Kita tentu paham, bahwa Negara Indonesia ialah negara kesatuan yang berbentuk Republik yang bersandarkan atas hukum. sedangkan makna yang terkandung dalam

\footnotetext{
${ }^{9}$ Dahlan Thaib, (2009), Ketatanegaraan Indonesia; Perspektif Konstitusional, Yogyakarta: Total Media, hlm 41.

${ }^{10}$ Jimly Asshiddiqie, (2009), Menuju Negara Hukum yang Demokratis, Jakarta: Bhuana Ilmu Populer, hlm.35

11 J Kaloh, (2009), Kepemimpinan Kepala Daerah: Pola Kegiatan, Kekuasaan, dan Perilaku Kepala Daerah dalam Pelaksaan Otonomi Daerah, Jakarta: Sinar Grafika, hlm. 4.
} 
Pasal 1 ayat 1 Undang-Undang Dasar Negara Republik Indonesia Tahun 1945 itu sendiri menunjukkan, bahwa negara Republik Indonesia yang diproklamirkan pada tanggal 17 Agustus 1945 dibangun dalam sebuah kerangka negara kesatuan bukan negara federasi. Sebagai negara kesatuan, Republik Indonesia hanya terdiri atas satu pemerintahan yakni pemerintahan pusat. Indonesia sebagai negara kesatuan terbagi atas daerah-daerah Provinsi dan daerah Provinsi terbagi atas daerah-daerah Kabupaten dan Kota. Setiap daerah tersebut mempunyai kewenangan yang diberikan berdasarkan peraturan perundangundangan, dimana daerah mempunyai kewenangan untuk mengatur dan mengurus rumah tangganya sendiri dalam bingkai otonomi daerah. ${ }^{12}$ Dengan logika mengurus "rumah tangga" sendiri inilah, perintah konstitusi bisa dijadikan modal substantifregulatif bagi pimpinan daerah untuk membumikan perintah konstitusi yang menggariskan hak kebhinekaan. Pimpinan daerah ini bisa mengajak atau melibatkan pergurian tinggi (PT). karena PT mempunyai sumberdaya, khususnya SDM yang andal dalam merealisasikan pembumian hak kebhinekaan, di samping PT sendiri sudah mempunyai kewajiban dalam kurikulum yang sudah dikonstruksinya, kalau pengajaran konstitusi sebagai keilmuan yang harus ditransformasikan kepada mahasiswa.
Terbukti sudah ada bebarapa PT di wilayah Malang Raya yang meerapkan kebijakan bersifat pelarangan terhadap mahasiswa yang ditengarai dari kelompok eksklusif atau kelompok yang mengasumsikan kalau apa yang dikenakan atau dijalankan adalah yang paling benar.

Kalau prinsip mulia itu bisa diwujudkan atau berhasil membumi, maka negeri ini akan menjadi kuat dan progresif dalam kultur kebhinekaan dan sedikit demi sedikit mampu mereduksi pola-pola pembenaran berlaku radikalisme dan ekstrimisme, disamping prinsip mulia itu akan mengedukasikan atau mencerdaskan dan mencerahkan pikiran dan perilaku masing-masing subyek sosial, politik, agama, budaya, dan lain sebagainya bergiat diri dalam menjalankan dan mengembangkan (memprogresivitaskan) kebajikan untuk semua dalam bingkai keragaman (secara pluralitstik).

\section{KESIMPULAN}

Kalangan pembelajar tentulah paham, bahwa konsitusi Indonesia (UUD 1945) merupakan hukum dasar yang mengatur kehidupan bermasyarakat, berbangsa, dan bernegara bagi rakyat di negara ini. Salah satu ketentuannya adalah mengenai hak hidup atas keragaman (kebhinekaan), dan bukan keragaman. Secara konstitusionalitas berarti ada pengakuan, bahwa setiap warga negara

\footnotetext{
${ }^{12}$ Krishna D Darumurti dan Umbu Rauta, (2003), Otonomi Daerah ; Perkembangan Pemikiran, Pengaturan dan Pelaksanaan, Citra Aditya Bakti, Bandung, hlm. 7.
} 
Indonesia mempunyai hak kebhinekaan, sehingga hak ini menuntut setiap siapapun atau pihak manapun untuk menghormatinya, dan bukan melecehkan atau mempermainkannya.

Kondisi paradok masih gampang ditemukan di tengah masyarakat, bahwa masih banyak orang atau pihak yang tidak menghormati hak kebhinekaan ini. Ada seseorang atau segolongan orang yang terjerumus memaksakan pendapat, sikap, dan perilakunya pada orang atau pihak lain untuk mengikutinya, meskipun jelas-jelas ini merupakan bentuk praktik pelanggaran konstitusi. Supaya hak kebhinekaan dihormati sebagai hak konstitusionalitas, peran strategis pemimpin daerah dengan cara melakukan berbagai bentuk kerjasama seperti dengan PT dapat dilaksanakan atau dikembangkan.

\section{DAFTAR PUSTAKA}

Abu Daud Busro dan Abu Bakar Busro, 1983, Asas-asas Hukum Tata Negara, Jakarta: Ghalia Indonesia.

A.V. Dicey, 1971, An Introduction to the Study of the law of the Constitution, London: English Language Book Society and Mac Hillan.
Dahlan Thaib, 2009, Ketatanegaraan Indonesia; Perspektif Konstitusional, Yogyakarta: Total Media.

Hestu Cipto Handoyo, 2009, Hukum Tata Negara Indonesia, Yogyakarta: Universitas Atma Jaya.

Jimly Asshiddiqie, 2009, Menuju Negara Hukum yang Demokratis. Jakarta: Bhuana Ilmu Populer.

J Kaloh, 2009, Kepemimpinan Kepala Daerah: Pola Kegiatan, Kekuasaan, dan Perilaku Kepala Daerah dalam Pelaksaan Otonomi Daerah, Jakarta: Sinar Grafika.

Kholilurrahman Saad, 2015, Kewajiban Bela Negara: Menjaga Kebhinekaan Indonesia, Bandung: Kalimas.

Krishna D Darumurti dan Umbu Rauta, 2003, Otonomi erah; Perkembangan Pemikiran, Pengaturan dan Pelaksanaan, Bandung: Citra Aditya Bakti.

Mochtar Hariri, 2015, Menjaga Negara Kebangsaan di Tengah Multikulturalisme, Jakarta: Leterasi-press.

Moh Mahfud MD, 2009, Konstitusi dan Hukum Dalam Kontroversi Isu, Jakarta: Raja Grafindo Persada

Ni'matul Huda, 2008, UUD 1945 dan Gagasan Amandemen Ulang, Jakarta: Raja Grafindo Persada.

\section{Internet}

Marsudi AR, Merajut Nasionalisme dalam Bingkai Kebhinekaan, http://banjarmasin.tribunnews.com/2017/ 01/26/merajut-nasionalisme-dalambingkai-kebhinnekaan, akses 1 April 2019. 